\title{
The Voice of the Author in Lolita
}

\author{
PANG Ren-shan \\ Shandong University of Science and Technology, Qingdao, Shandong, China
}

\begin{abstract}
There is the voice of the author in Vladimir Nabokov's Lolita. Readers can hear the voice from forword, the story, and afterword. In the Forword, Vivian Darkbloom is the palindromic name of the author Vladimir Nabokov. In the noval, the word "throb" indicates the voice of the author. And in the Afterword, the word "throb" is also used, which indicates the voice of the author. Therefore, readers can hear the voice of the author to better understand the novel.
\end{abstract}

Keywords: Vladimir Nabokov, voice, palindromic, throb

\section{Introduction}

Lolita is a great novel written by Vladimir Nabokov. Many people have been studying the great novel since its publication. In 2004, LANG Xiao-ling studied the irony of Nabokov's novels, so irony was touched. Readers can understand Nabokov's novels in this way. In 2004, LIU Jia-lin studied Nabokov's concept of literature which is another way to understand Lolita. In 2005, LUO Gui-bao studied language art of Lolita which helps a lot in understanding the novel. MA Ling studied Nabokov's butterfly aesthetics which is another way to enjoy the novel. In 2004, PAN Li-feng studied two mystries in the novel. In 2003, WANG Qing-song studied realism in the novel. In 2002, YANG Zhen-yu studied the detail in the novel. But In this novel, there is the voice of Vladimir Nabokov which has never been studied, so it is important to study the voice of Nabokov in Lolita. Knowing the voice of the author can help readers a lot in understanding the novel.

\section{The Foreword}

In the foreword on page four and five, there are the following words:

For the benefit of old-fashioned readers who wish to follow the destinies of the "real" people beyond the "true" story, a few details may be given as received from Mr. Windmuller of Ramsdale, who desires his identity suppressed so that "the shadow of this sorry and sordid business" should not reach the community to which he is proud to belong. (Nabokov, 2000, p. 4)

His daugter, Louise, is by now a college sophomore. Mona Dale is a student in Paris. Rita has recently married the proprietor of a hotel in Florida. Mrs. Rchard Schiller died in childbed, giving birth to a stillborn girl, on Christmas Day in 1952, in Gry Star, a settlement in the remost northwest. Vivian Darkbloom has written a biography, My Cue, to be published shortly, and critics who have perused the manuscript call it her best book. The caretakers of the various cemeteries involved report that no ghosts walk. Here, Mrs. Richard Shuller refers to

PANG Ren-shan, associate professor, master, College of Foreign Languages, Shandong University of Science and Technology. 
lilita which will be known towards the end of the novel. Vivian Darkbloom refers to the author who is the palindromic version of Vladimir Nabokov. So Vivian Darkbloom indicates the voice of the author. Although the foreword is written in the name of John Ray, it is a layered narrative. There is the author there. The foreword gives a sense of reality which suggests the fictionality as a veneer.

On page five, there is the following words:

This commentator may be excused for repeating what he has stressed in his own books and lectures, namely that "offensive" is frequently a synonym for "unusual;" and a great work of art is of course always original, and thus by its very nature should come as a more or less shocking surprise. (Nabokov, 2000, p. 5)

I have no intention to glorify "Humbert Humbert". No doubt, he is horrible; he is abject; he is a shining example of moral leprosy, a mixture of ferocity and jocularity that betrays supreme misery perhaps, but is not conducive to attractiveness. He is ponderously capridious. Many of his casual opinions on the people and scenery of this country are ludicrous. A desperate honesty that throbs through his confession does not absolve him from sins of diabolical cunning. He is abnormal. He is not a gentleman. But how magically his singing violin can conjure up a tendresse, a compassion for Lolita that makes us entranced with the book while abhorring its author. Here, "throb" is used to describe Humbert, but "throb" reveals Nabokov. "His singing violin" also reveals the voice of Nabokov. Because in his forword to Invitation to a Beheading, Nabokov calls the noval a "violin in a void", and in Speak, Memory he calls the poet Boris Poplavski "a far violin among near balalaikas".

\section{The Story}

There are the followintg words when Humbert wonders what happens to the little nynphets:

I have often wondered what became of those nymphets later? In this wrought-iron world of criss-cross cause and effects, could it be that the hidden throb I stole from them did not affect their future? I had possessed her and she never knew it. Allright. But would it not tell sometime later? Had I not somehow tampered with her fate by involving her image in my voluptas? Oh, it was, and remains, a source of great and terrible wonder. (Nabokov, 2000, p. 21)

Here, "throb" is used .

The word "throb" is used by Nabokov many times, and "throb" is always associated with Lolita.

On page 61, the noval has the following words:

Oh it's nothing at all," she cried with a sudden shrill note in her voice, and she wiggled, and squirmed, and threw her head back, and her teech rested on her glisterning underlip as she half-turned away, and my moaning mouth, gentlemen of the jury, almost reached her bare neck, while I crushed out against her left buttock the last throb of the longest ecstasy man or monster had everknown. (Nabokov, 2000, p. 61)

Here the word "throb" refers to Humbert's desire to possess Lolita. In the previous sentences, Humbert describes his psychology: ...save the infusion of joy brewed within my body. Humbert also describes his action: ...for there was, I swear, a yellowish-violet bruise on her lovely nymphet thigh which my huge hairy hand massaged and slowly enveloped - and because of her very perfunctory underthings, there seemed to be nothing to prevent my muscular thumb from reaching the hot hollow of her groin — just as you might tickle and caress a giggling child— just that... (Nabokov, 2000, pp. 60-61)

Therefore, the word "throb" is associated with Humbert's desire for Lolita.

On page 31, the novel has the following words: 
Quilty, Clare, American dramatist. Born in Ocean City, N.J., 1911. Educated at Columbia University. Started on a commercial career but turned to playwriting. Authur of The Little Nymph, The Lady Who Loved Lightning (in collaboration with Vivian Darkbloom), Dark Age, The Strange Mushroom, fatherky Love, and others. His many plays for children are notable. Little Nymph (1940) traveled 14,000 miles and played 289 performances on the road during the winter before ending in New York. Hobbies: fast cars, photography, pets. (Nabokov, 2000, p. 31)

Here Vladimir Nabokov's palindromic name Vivian Darkbloom appears. So Nabokov drops in.

On page 66, the noval has the following words:

One drop of rare honey, however, that Thursday did hold in its acorn cup. Haze was to drive her to the camp in the early morning. Upon sundry sounds of departure reaching me, I rolled out of bed and leaned out of the window. Under the poplars, the car was already a throb. On the sidewalk, Louise stood shading her eyes with her hand, as if the little traveler were already riding into the low morning sun. The gesture proved to be premature. "Hurry up" shouted Haze. My Lolita, who was half in and about to slam the car door, wind down the glass, wave to Louise and the poplars (whom and which she was never to see again), interrupted the motion of fate: She looked up and dashed back into the house (Haze furiously calling after her). A moment later I heard my sweet heart running up the stairs. My heart expanded with such force that it almost blotted me out. I hitched up the pants of my pajamas, flung the door open: and simultaneously Lolita arrived, in her Sunday frock, stamping, panting, and then she was in my arms, her innocent mouth melting under the ferocious pressure of dark male jaws, my palpitating darling The next instant I heard her alive, unraped clatter downstairs. The motion of fate was resumed. (Nabokov, 2000, p. 66)

Here because Lolita is in the car, and the car is leaving for the camp, so the car is a throb for Humbert. And the word "throb" indicates Hunbert's desire for Lolita. Once again Nabokov drops in.

On page 87 , the noval has the following dords:

Ladies and gentlemen of the jury, the majority of sex offenders that hanker for some throbbing, sweet-moaning, physical but not necessarily coital, relation with a girl-child, are innocuous, inadequate, passive, timid strangers who merely ask the community to allow them to pursue their practically harmless, so-called aberrant behavior, their little hot wet private acts of sexual deviation without the police and society cracking down upon the $\mathrm{m}$. We are not sex fiends We do not rape as good soldiers do. We are unhappy, mild, dog-eyed gentlemen, sufficiently well integrated to control our urge in the presence of adults, but ready to give years and years of life for one chance to touch a nymphet. Emphatically, no killers are we. Poets never kill. Oh, my poor Charlotte, do not hate me in your eternal heaven among an eternal alchemy of asphalt and rubber and metal and stone but thank God, not water, not water. (Nabokov, 2000, p. 87)

As usual, the word "throb" once again indicates Humbert's desire for Lolita. So Nabokov drops in.

On page 109 , in paragraph 26 , there is also the voice of Nabokov:

This daily headache in the opaque air of this tombal joil is disturbing, but I must persevere. Have written more than a hundred pages and not got anywhere yet. My calender is getting confused. That must have been aroud August 15, 1947. Don't think I can go on. Heart, head-everything. Lolita, Lolita, Lolita, Lolita, Lolita, Lolita, Lolita, Lolita, Lolita. Repeat till the page is full, printer. (Nabokov, 2000, p. 109)

Humbert died in prison on November 16, 1952, so Humbert could not be in prison writing the novel on August 15, 1947. Therefore, it reveals the voice of Nabokov.

\section{The Afterword}

In the afterword, "throb" is also used in paragraph three of page 211:

The first little throb of Lolita went through me in 1939 or early in 1940, in Paris, at a time when I was laid up with a severe attack of intercostal neurolgia. As far as I can recall, the initial shiver of inspiration was somehow prompted by a 
newspaper story about an ape in the Jordin des Plantes, who, after months of coaxing by a scientist, procuced the first drawing ever charcooled by an animal: This sketch showed the bars of the poor creature's cage. The inpulse I record had no textual connection with the ensuing train of thought, which resulted, however, in a prototype of my present novel, a short story some thirty pages long. I wrote it in Russian, the language in which I had been writing novels since 1924 (the best of these are not translated into English, and all are prohibited for political reasons in Russia). The man was a central European, the anonymous nymphet was French, and the loci were Paris and Provence. I had him marry the little girl's sick mother who soon died, and after a thwarted attempt to take advantage of the orphan in a hotel room, Arthur for that was his name) threw himself under the wheels of a truck. I read the story one blue-papered wartime night to a group og friends-Mark Aldanov, two social revolutionaries, and a woman doctor; but I was not pleased with the thing and destroyed it sometime after moving to America in 1940. (Nabokov, 2000, p. 211)

Here, Nabokov uses "throb" to refer to the impulse of writing Lolita. In paragraph two of page 312, the word "throb" is also used: Around 1949, in Ithaca, upstate New York, the throbbing, which had never quite ceased, began to plague me again. Combination joined inspiration with fresh zest and involved me in a new treatment of the theme, this time in English - the language of my first governess in St. Petersburg, circa 1903, a Miss Rachel Home. The nymphet, now with a dash of Irish blood, was really much the same lass, and the basic marrying-her-mother idea also subsisted; but otherwise the thing was new and had grown in secret the claws and wings of a novel. (Nabokov, 2000, p. 312)

In the afterword, the impulse to write Lolita is described as "throb". And in the novel, "throb" is related to the physical desire of Humbert. Nabokov is in the word "throb".

\section{Conclusion}

From the above mentioned, it is clear that in the foreword, Vivian darkbloom is the palindromic version of Vladimir Nabokov though it is in the name of John Ray. In the story, the word "throb" is used many times, and they are all associated with Humbert's physical desire for Lolita. In the afterword, Vladimir Nabokov's impulse to write Lolita is described as "throb". In addition, on page 109, there is the words: That must have been around August 15, 1947 (Nabokov, 2000, p. 109). It can not be 1947, because Humbert died in 1952 while writing the story. So these words also reveals the voice of Nabokov.

Thus, Vladimir Nabokov is in Vivian Darkbloom. Vladimir Nabokov is in the word "throb". In this way, we can hear the voice of Vladimir Nabokov which is helpful to the understanding of Lolita.

\section{References}

LANG, X. L. (2004). Laugh in the dark-Irony of Nabokov's Novals. Thoery Journal, 6, 115-117.

LIU, J. L. (2004). On Nabokov's concept of literature. Journal of Yangzhou University (Humanities \& Social Sciences), 6, 33-38.

LUO, G. B. (2005). Language art of Lolita. Journal of Liaocheng University (Social Sciences), 2, 106-109.

MA, L. (2004). Nabokov's butterfly-aesthetics. Journal of Hit (Social Sciences ed.), 2, 20-24.

Nabokov, V. (2000). Lolita. London: Penguin Books.

PAN, L. F. (2004). Pursuing the enigma of humanity: An interpretation of two mysteries in Nabokov and Lolita. Journal of Social Science of Hunan Normal University, 4, 115-118.

WANG, Q. S. (2003). Returning to realism: A type of decoding Lolita. Journal of Shanghai Teacher's University (Phylosophy \& Social Sciences), 3, 88-93.

YANG, Z. Y. (2002). God is in the detail: An expatiation on the Novel Lolita. Foregn Literature, 2, 82-86. 